\title{
Application of Role-Playing Methods to Improve Learning Outcome of Learning Indonesian in Class V Students Primary School
}

\author{
Hetty J. Tumurang \\ Department of Primary School Teacher Education \\ Universitas Negeri Manado, Indonesia \\ tumuranghetty@gmail.com
}

\begin{abstract}
The purpose of this study is to improve role playing about drama in Indonesian language subjects for Imanuel Karatung Christian elementary school students. The number of students is 18 children, consisting of 11 male students and 7 female students, this research is classroom action research (PTK). PTK research was conducted in the 2016-2017 school year, in the second semester of February. Data collection techniques were used through tests and non-tests, before the research was held, researchers conducted pre-cycle activities. The results of the class average in the first cycle were 67.13 the number that met the KKM 12 students (66.66\%), student activities 6.28 (69.78\%) and teacher performance 76.43 (B). in the second cycle also experienced an increase the class average becomes 84.53 numbers that meet KKM as many as 18 students (100\%), student activities $7.72(85.78 \%)$ and teacher performance 89.04 (A). From the data obtained it can be concluded that the application of role-playing methods can improve the learning outcomes and activities of students in drama material on Indonesian language subjects in Class V students of Imanuel Karatung Christian Elementary School.
\end{abstract}

Keywords: role playing, learning outcome, learning Indonesian, primary school

\section{INTRODUCTION}

Primary school is part of basic education which has one goal that develops aspects of knowledge, skills, attitudes and values, which always refers to the applicable curriculum. This is in accordance with the basic education objectives contained in PP No. 28 of 1990 article 3 reads basic education aims to provide basic skills provision to students to develop personal life, community members, and citizens and prepare students to take education to a higher level.

One of the innovative subjects missed in the curriculum is Indonesian. In the subject curriculum there are four skills that must be mastered by students. From the four skills contained in the appreciation of literature which consists of three parts (prose, poetry and drama) appointed in this election one of literary appreciation namely drama.

The method of role playing is a form of learning that organizes learning activities in the form of conversation. The intention is to train students to dare to appear in speaking skills. Speaking is very important in learning [5] in this model students examine the problem of joint humans by solving situations that exist in the text to be delivered or played in the text to be delivered or played, then students will be directly involved in the learning process.

Playing the role (role playing) is an instruction set on experience equips students with an alternative learning experience means that teaching is based on the experience gives students a set or series of situations studied in the form of the involvement of actual experience designed by the teacher [8].

Furthermore, it was explained that an increase in student learning achievement is one aspect that becomes the goal in learning as an innovation, role playing can provide sufficient scope, clear to students to develop their academic potential. The tendency of teacher-centered learning or switch to student-centered learning [14].

Learning will become more meaningful when students experience themselves and are not bored in taking lessons. Because learning that is meaningful will open students to impressive teaching experiences.

Based on the above background, the formulation of the problem determined by the researcher is how to apply the role-playing model to improve the learning outcomes of Indonesian about drama material in the fifth grade of Imanuel Karatung Christian Elementary School?

The purpose of this study is to improve student learning outcomes through the application of (Role Playing) to improve the learning outcomes of Indonesian about drama material in the fifth grade of Imanuel Karatung Christian Elementary School.

Benefits Research from the results of research is expected to provide the following benefits: (i) For Researchers: Add insight, improve skills in developing teaching methods for learning Indonesian Language materials (ii) For Schools: As a reference in institutions to apply appropriate lessons to support, improve the school itself (iii) For Students: Can improve student learning outcomes and can facilitate students in receiving lessons.

\section{METHODS}

According to Kemmis and McTaggart (Kasbullah, 1998) suggests that action research is a form of reflective research conducted by actors in the social community and aims to improve their work. Understand this work and where this work is done. Furthermore, in another part of Kemmis and McTaggart (Kasbullah, 1998) suggests that class action research (PTK) is described as a dynamic process in which four aspects, namely planning, action, observation and reflection must be understood not as a 
static step resolved with itself but rather are moments in the spiral aspect.

The study was planned to be carried out in two cycles. Cycle 1 consisted of two meetings, one learning meeting and one meeting for evaluation. The research process used in this study can be seen through the picture below (Figure $1)$.

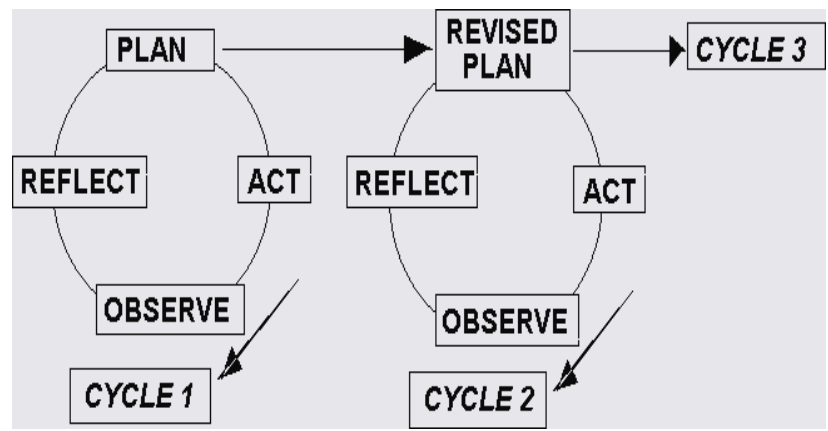

Figure 1

Design of PTK (Arikunto, 2009)

\section{Cycle I}

Cycle I includes: introductory activities and closing cycles I hold two meetings once for learning and once for evaluation, one lesson consisting of two hours of study. The following is a description of activities in the first cycle.

\section{Planning}

From the results of reflection, researchers formulated operational problems, especially in the use of roleplaying methods in learning and student reactions to the material, then the researchers compiled the following actions:

- Determine the basic competencies to be taught.

- Making RPP during cycle I.

- Install media planning, learning resources and student worksheets.

- Define assessment criteria.

- Arrange class processing in making small groups with 3-5 members with heterogeneous abilities.

- Compile a data collection tool such as a validation sheet for student learning activities.

- Prepare a data collection plan

\section{Implementation of actions}

In implementing the action, the researcher collects learning methods with relevant partner benefits. The researcher keeps the observation and evaluation instruments right in accordance with the stages of the role playing method (role playing)) in the first cycle carried out by conveying information classically at the first meeting, the meeting of the two students plays a drama script followed by explaining the student worksheet in groups and giving evaluations and giving independent assignments, during the learning process the teacher acts as a researcher observing if there are difficulties in group members how to complete the work, the researcher is tasked with guiding students who have difficulty in completing the task of student progress carried out by the teacher who acts as a researcher students' progress in learning measured by individual questions assessing students in groups (performance) and student performance.

\section{Observation}

Observation is carried out in collaboration with colleagues on the teacher in accordance with the objectives of the study. Observations are focused on: (1) Student learning outcomes include class averages, the number of students who complete learning in a classical manner, (2) Student activities include the presence of students earnest when studying in class, student responsibility in doing group assignments, and (3) teacher performance in the learning process includes, learning implementation plan (RPP) and implementation of learning.

\section{Reflection}

Reflection as an evaluation material sets the conclusions contained in the research that are used as recommendations for the next action plan

\section{Cycle II}

Cycle II includes: the introduction of the main activities and the closing of the second cycle carried out in two one-time meetings for learning and once for evaluation, one-time learning consisted of two lesson hours.

\section{Planning}

From the results of reflection, researchers formulated operational problems, especially in the use of roleplaying methods in learning and student reactions to the material, then the researchers compiled the following actions:

- Determine the basic competencies to be taught.

- Making RPP during cycle II.

- Install media planning, learning resources and student worksheets.

- Define assessment criteria.

- Arrange class processing in making small groups with 3-5 members.

- with heterogeneous abilities.

- Arrange data collection tools such as validation sheets for student learning activities.

- Prepare a data collection plan.

\section{Implementation of actions}

Implementation of the second cycle is an improvement of the implementation cycle of the implementation of the action I. A teacher is a role-playing methods (role playing) in the second cycle supported by the relevant partners and instruments of observation and proper evaluation and repair components are not maximized learning It is expected that the implementation of the action in the second cycle of students has mastered and understood the values given so that the indicators can be achieved.

\section{Observation}

Observation is carried out in collaboration with colleagues on the teacher in accordance with the objectives of the study. Observations are focused on: (1) Student learning outcomes include class averages, the number of students who complete learning in a classical manner, (2) Student activities include the presence of students earnest when studying in class, student responsibility in doing group assignments, (3) teacher performance in the learning 
process includes, learning implementation plan (RPP) and implementation of learning.

\section{Reflection}

Data analysis and reflection are carried out collaboratively with colleagues to analyze all activities carried out in the first cycle, in addition, to find out the achievement of student learning outcomes analysis is also conducted to determine the strengths and weaknesses in the teaching and learning process in the class II. Based on the results of the analysis in cycles I and II of the learning outcomes of student learning activities and teacher performance, the researcher will conclude whether the hypothesis is achieved or not. If learning outcomes, student activity and teacher performance as indicators (increase), then the role-playing method that is expected in learning can improve the learning outcomes of fifth grade students of Imanuel Karatung Christian Elementary School.

The subjects in this study were the fifth-grade students of Imanuel Karatung Christian Elementary School in the 2016-2017 Academic Year with 18 students, with 11 male students and 7 female students. Place and time of research. This classroom action research was carried out in class $\mathrm{V}$ on Indonesian language subjects on drama in Imanuel Karatung Christian Elementary School, Nanusa Subdistrict, Talaud Islands District. The study was conducted in semester 2. Data analysis technique is a method used by researchers to process the data obtained: quantitative data obtained from the results of formative tests of students in the role in which in the first cycle and second cycle. The data obtained is then analyzed by the following steps:

- Making recapitulation of written values and grades of student performance

- Calculating the final value

- Calculate the class average value

- Completely calculate classical learning

Determine the final value of learning outcomes obtained by students:

$\mathrm{NA}-\frac{S P}{S M} \times 100$

Note:

SP : Earnings Score

SM : Shoes Maximum

To determine the class average:

$\mathrm{M}=\sum \frac{X}{N}$

\section{Note:}

M : Average value

$\sum \mathrm{x}$ : Final value

$\sum \mathrm{n}:$ Number of students

Complete presentation of classical learning:

Complete classics: $\frac{\text { the number of students completed }}{\text { the number of students }} \times 100 \%$

\section{RESULTS AND DISCUSSION}

\section{Results of cycle I}

The average test cycle in the new pre-cycle activities reached 61,55. The average obtained has not yet reached the KKM in Imanuel Karatung Christian Elementary School, the specified KKM which is equal to 65 while the average value obtained has only reached 61.55 , the average value of 61.53 indicates that the class average value can be seen from 18 students who take the new pre-cycle test 6 students who meet the KKM or have been sincere with a percentage of $33.33 \%$ need to be improved again.

\section{Cycle II results}

The test results in the second cycle are the results of the test after the action was taken on the material playing the drama. Actions were carried out to solve the problems that appeared in the first cycle. In the first cycle the test scores were not maximal, because there were still 6 students who did not meet the second cycle has increased. The value of the class average in the second cycle there is an increase compared to the average value in the first cycle and second cycle, in the first cycle get an average value of 67, after the improvement in the second cycle was 84.53.

The aim of the PTK is to use role playing methods to improve the learning outcomes of Indonesian language about drama at Imanuel Karatung Christian Elementary School To achieve the research objectives, the researcher sets out the problem formulation, the researchers determined the problem: What is the Role Playing Method Improving Skills Play Drama on Student Class V Sd Christian Emmanuel Karatung? Hypothesis of a formulation of the problem that has been set, namely: By Applying method Role Playing (Role Playing) Can Improve Skills Play Drama on Student Class V Sd Christian Emmanuel Karatung. for more details would describe the discussion of the results of the research that has been obtained. The discussion was focused on learning outcomes data, the results of observations on student learning activities and teacher performance. In the discussion to be clearer, it will be explained about the meaning of the research findings and the implications of the results of the researchers.

The results of the first cycle test on drama material scored a new class average of 67 as many as 6 students got a value of $<65$ or $33.33 \%$. The target set by researchers was an average grade of $<65$ or $70 \%$. The average results obtained have not reached the set target, because: (1) students feel alien to the use of role playing methods, evidenced by student confusion when the teacher tells students to practice role playing in drama material; (2) students' perceptions of the media displayed by the teacher make students not focus on drama material, giving students focused on the media displayed by the teacher; (3) teachers still approach and focus classically so that students whose understanding of learning is slow, values are still below the $\mathrm{KKM}$; (4) the teacher is too fast in delivering the material, causing students to not understand the material of the drama delivered; (5) the teacher is too quick to exemplify correct drama dialogue; (6) the teacher's voice is less strict in delivering the material, so students who sit behind are less observant to hear the teacher's explanation; (7) 
teachers lack motivation to students both verbally and noverbal; (8) the learning done is not maximal, because spatial planning is less effective for learning. Problems in cycle Iwill be corrected in cycle II. In the second cycle the class average value reached 84.53 , the results of the class average value in the second cycle had met the target set. Research does not need to add to the cycle, because II cycles meet the minimum criteria of 65 .

\section{CONCLUSION}

Based on the results of the research and discussion, it was concluded that the application of role-playing methods could improve the learning outcomes of Indonesian students of fifth grade SD GMIM Imanuel Karatung. Based on the conclusions of the results of the study, it is expected that: (1) students do not get bored and have difficulty in drama material, so that learning outcomes can be achieved optimally (2) The school should motivate (3) teachers to use innovative learning methods so students do not feel saturated with conventional. For example, learning, for example by the application of methods play a role (role playing) on the subject of drama.

\section{REFERENCES}

[1] Aminudin 1997, Isi Dan Strategi Pengajaran Bahasa dan Sastra. Malang: Airlangga.
[2] Aqip, 2.2002.Profesionalisme dalam Pembelajaran. Jakarta: Insan Candekia.

[3] Hasan Hamid. 1992/1993. Evaluasi Hasil Belajar. Jakarta: Depdikbud.

[4] Kunandar, 2007. Guru Profesional Implementasi Kurikulum Tingkat satuan pendidikan dan sukses dalam sertifikasi Guru. Jakarta: Raja Grafindo. Persada.

[5] Luxemburg, J.V. 1997 pengantar ilmu sastra, Jakarta: Alfabeta.

[6] Mulyasa, S.2008. Menjadi Guru Profesional:Menciptakan Pembelajaran Kreatif dan Meyenankan.Malang: Airlangga.

[7] Rusyana. 1994. Metode Pengajaran Sastra. Bandung: Gunung Larang.

[8] Sanjaya Wina.2006. Strategi Pembelajaran Berorientasi. Standart Proses Pendidikan. Bandung: Bumi Aksara.

[9] Santosa Pudji. 2003. Materi dan Pembelajaran. Bahasa Indonesia SD. Jakarta: Universitas Terbuka.

[10] Sudjana, H. Nana.1996. Cara Belajar Siswa Aktif. Dalam proses belajar mengajar. Bandung: Sinar Baru Agensido.

[11] Syafi'I, Imam. 1999. Pengajaran Membaca di SD. Malang: UM.

[12] Suyanto, K.K.E.1997. Penelitian Tindakan Kelas Sebagai Refleksi Pengajaran. Malang: PPS UM.

[13] Uno, B. Hamza. 2007. Model Pembelajaran Menciptakan Proses Belajar Mengajar yang Kreatif dan Eektif. Bandung: Bumi Aksara.

[14] Yamin Martinis. 2007. Profesionalisme Guru dan Implementasi KTSP. Jakarta: Gaung Persada Pers.

[15] Sukini. 2008. Bahasa Indonesia. Jakarta: Eureka. 